\title{
НОВЫЕ АРХЕОЗООЛОГИЧЕСКИЕ ИССЛЕДОВАНИЯ СРЕДНЕВЕКОВОГО БИЛЯРА
}

\section{(С) 2021 г. Д.Н. Шаймуратова, И.В. Аськеев, 3.Г. Шакиров}

В статье представлено новое исследование остатков рыб и птиц из раскопа XLIV Билярского городища, заложенного с целью изучения крупного кирпичного здания, который располагался в так называемом «Внутреннем городе» - наиболее статусной его части. Целью работы являлся комплексный анализ фаунистических остатков, извлеченных из культурного слоя методом послойного отбора с просеиванием. По костным остаткам и чешуе определено 23 вида рыб с преобладанием остатков крупноразмерных видов: севрюги, судака, стерляди и белорыбицы. Преобладание крупноразмерных видов указывает на то, что промысел велся на Волге и Каме, и основной состав рыб, употреблявшихся на городище, был привозной. Видовой состав птиц высок и разнообразен - 40 видов диких и 3 вида домашних птиц с доминированием домашней курицы. Среди диких птиц интересны находки элементов скелета хищных птиц из отряда Ястребиных и отряда Соколов, что указывает на наличие соколиной охоты на данном местонахождении и его высокий социальный статус.

Ключевые слова: Среднее Поволжье, средневековье, Биляр, остатки рыб и птиц, метод послойного отбора с просеиванием.

\section{NEW ARCHAEOZOOLOGICAL STUDIES OF MEDIEVAL BILYAR}

\section{D.N. Shaimuratova, I.V. Askeyev, Z.G. Shakirov}

The paper discusses a new study of fish and bird remains from excavation XLIV of Bilyar fortified settlement, founded in order to study a large brick building located in the so-called "Inner City" - the part of the settlement with the highest status. The aim of the study was a comprehensive analysis of faunal remains extracted from the cultural layer using the method of layer-by-layer sampling and sieving. On the basis of bone remains and scales, a total 23 fish species were identified with predominant remains of large species: Starred sturgeon, Zander, Sterlet and Whitefish. The predominance of large species indicates that fishery was practiced on the Volga and Kama rivers, and the bulk of the fish consumed at the site was imported. The species composition of birds is high and diverse -40 species of wild and 3 species of domestic birds with predominant domestic chicken. Of interest among wild birds are the finds of skeleton fragments of the birds of prey of the Accipitriformes and Falconiformes order, which indicates the presence of falconry in the area, and its high social status.

Keywords: archaeology, archaeozoology, Middle Volga region, Middle Ages, Bilyar, fish and bird remains, layer-by-layer sampling and sieving method.

\section{Введение}

На территории Республики Татарстан находится много средневековых археологических памятников. Наибольший интерес вызывают археологические памятники, которые в период функционирования являлись городскими поселениями с высоким социальным статусом, развитыми торговыми связями и большой аккумулятивной способностью, такие как средневековый Биляр.

Остатки животных, полученные в ходе раскопок, наряду с вещевым материалом, являются весьма информативными для характеристики значения различных групп животных в жизни жителей, а также уровня благосостояния и общего социально-экономического статуса древних поселений. В данной работе представлены новые результаты исследования остатков рыб и птиц из раскопа XLIV Билярского городища с применением мето- да послойного отбора с просеиванием, что позволило извлечь из культурного слоя городища фаунистические остатки всех размерных категорий.

\section{Материал и методика}

Памятник федерального значения «Городище «Биляр» - одна из столиц Болгарского государства», географически расположен на p. Малый Черемшан, впадающей в р. Большой Черемшан - левый приток р. Волги. Территория Билярского городища $\mathrm{X}$ - начала XIII вв., окруженная концентрически вписанными земляными валами и рвами, которые делят его на внутренний и внешний город, составляет примерно 620 га. Проанализированная археозоологическая коллекция происходит из раскопа XLIV, где изучены напластования и более семидесяти объектов, датирующихся преимущественно XI в. 1236 г. (раскопки 2015-2018 гг. под общим 
руководством Шакирова 3.Г. и Хузина Ф.Ш.) (Хузин, Шакиров, 2017, с. 326-328; Бадеев и др., 2019, с. 331-334; Худяков и др.). Раскоп XLIV, заложенный с целью изучения крупного кирпичного здания, располагался в центральной части внутреннего города наиболее статусной части Билярского городища. Общая площадь раскопа составила 288 кв. м. Отбор фаунистических остатков проводился из культурных напластований, ям и сооружений по горизонтам с применением просеивания. Изучение остатков рыб и птиц проводилось с использованием стандартных методов, применяемых в археозоологии (Serjeantson, 2009, p. 1-418; Аськеев и др., 2013a, с. 1014-1015; Аськеев и др., 2013б, с. 118; Шаймуратова, 2016, с. 8-10). Видовая, анатомическая, морфологическая и половозрастная диагностика выполнена на базе сравнительной коллекции остатков современных и субфоссильных животных лаборатории биомониторинга ИПЭН АН РТ. Высокая сохранность костей позволила сделать почти полную видовую и морфологическую идентификацию: до вида было определено 87,9\% от всех костей рыб и 97,1\% от всех костей птиц.

\section{Результаты и обсуждение}

$P b l б b l$. Общее количество остатков рыб в коллекции за все годы раскопок составило 2115 экз. костей и 3 чешуи (табл.). Определено 23 вида рыб с преобладанием севрюги $(23,1 \%$ от всех костей рыб), судака $(15,2 \%)$, стерляди $(12,7 \%)$ и белорыбицы (10,9\%). На эти 4 вида рыб приходится 70,9\% от всех выявленных на раскопе костей рыб. Также определены кости каспийского лосося, европейского хариуса и разных видов карповых рыб. Кости сома и щуки малочисленны: несмотря на то, что эти виды являются средне-крупноразмерными, они не были предпочтительными в потреблении жителями Биляра. Размеры доминирующих в коллекции видов рыб были достаточно крупные. В целом размерный диапазон потреблявшихся рыб был от 20 см (среднеразмерная группа) до 3,5 метров (крупноразмерная группа) с преобладанием рыб с длиной тела 60-100 см. Соотношение крупноразмерных и среднемелкоразмерных таксонов рыб $(0,9)$ соответствует высокой эксплуатационной нагрузке на крупноразмерные виды рыб. Согласно анализу элементов скелета, было выявлено, что для судака абсолютными доминирующими элементами являлись позвонки. Кости головы и другие элементы скелета выявлены единично. То же отмечено для каспийского лосося и сома. Видимо, это связано со спецификой разделки этих видов рыб. Возможно, в городище привозили только туши без головы. Для остальных видов рыб подобная особенность не обнаружена.

Общее количество костей рыб и выявленный видовой состав свидетельствует о важности рыбы как пищевого ресурса для жителей средневекового Биляра. Средневековый Биляр располагался достаточно далеко от крупных рек Волги и Камы (приблизительно 45-60 км), где осуществлялся промысел осетровых, лососевых рыб и судака. Следовательно, все эти рыбы были привозными. Доминирование в коллекции костей от крупноразмерных и ценных видов рыб указывает на особые предпочтения в определенном видовом и размерном составе рыб. Доля средне- и мелкоразмерных рыб в диете была незначительной.

Птищьы. Общее количество костей птиц за все годы раскопок составило 1886 экз. Идентифицировано 3 вида домашних и 40 видов диких птиц (табл.). По количеству костей абсолютным доминантом являлись домашние куры - 1498 костей $(79,4 \%$ от всех костей птиц). Согласно размерам костей, домашних кур Биляра можно отнести к нескольким размерным типам. Имеются кости от очень крупных особей, особей среднего размера и мелких взрослых особей. Преобладают кости от крупного и среднего размерного типа. Генетический анализ костей кур из данного раскопа выявил принадлежность их к субгаплогруппе E1 (Lebrasseur et al, 2021, p. 224), распространенной во всем мире и доминирующей в Европе, Африке и Америке, и показал хорошее содержание эндогенной ДНК, что указывает на потенциал дальнейших генетических исследований костей птиц из Билярского городища. Также среди домашних видов птиц выявлены кости домашнего гуся $(4,4 \%)$ и домашней утки $(0,3 \%)$. Генетический анализ костей домашних гусей из Билярского городища показал их принадлежность к гаплотипам D3/D7, которые являлись одними из распространенных гаплотипов среди домашних гусей в Средневековье на территории Европейской части России (Honka et al, 2018, p. 367). Выявлено большое разнообразие диких птиц. Наиболее интересным является наличие элементов скелета хищных птиц из отряда ястребиных (3 вида: ястреб-тетеревятник, ястреб-перепелятник, беркут) и отряда соколов (2 вида - сапсан и кречет). Все эти виды относятся к потенциально ловчим хищным птицам. Находка остатков этих видов птиц 
Таблища. Видовой состав и общее количество костей/чешуи рыб и птиц из раскопа XLIV Билярского городища

Table. Species composition and the total number of bones/scales of fish and birds from excavation XLIV of Bilyar fortified settlement

\begin{tabular}{|c|c|c|c|c|c|}
\hline \multirow[t]{2}{*}{ Название вида (русское и латинское) } & \multicolumn{4}{|c|}{ Количество костей, в экз. } & \multirow[b]{2}{*}{$\begin{array}{l}\text { Общее за } \\
4 \text { года }\end{array}$} \\
\hline & 2015 & 2016 & 2017 & 2018 & \\
\hline \multicolumn{6}{|l|}{ Класс РЫБЫ PISCES } \\
\hline Русский осетр Acipenser gueldenstaedtii & 84 & 50 & 5 & 52 & 191 \\
\hline Стерлядь Acipenser ruthenus & 52 & 125 & 11 & 81 & 269 \\
\hline Севрюга Acipenser stellatus & 190 & 196 & 33 & 69 & 488 \\
\hline Белуга Huso huso & 22 & 3 & 4 & & 29 \\
\hline $\begin{array}{l}\text { Семейство Осетровые, ближе не определимые } \\
\text { Acipenseridae }\end{array}$ & 41 & 27 & 7 & 11 & 86 \\
\hline Золотой карась Carassius carassius & 1 & 4 & 1 & & 6 \\
\hline Сазан Cyprinus carpio & $\begin{array}{l}2 \text { кости } \\
1 \text { чешуя }\end{array}$ & 4 & 2 & 1 & 9 \\
\hline Лещ Abramis brama & 12 & $\begin{array}{c}11 \text { костей } \\
2 \text { чешуи }\end{array}$ & 35 & 11 & 69 \\
\hline Синец Ballerus ballerus & & 8 & 1 & & 9 \\
\hline Густера Blicca bjoerkna & 3 & 1 & & & 4 \\
\hline Язь Leuciscus idus & 1 & 2 & & & 3 \\
\hline Обыкновенная плотва Rutilus rutilus & 4 & 4 & 3 & 1 & 12 \\
\hline Голавль Squalis cephalus & & 1 & & & 1 \\
\hline Линь Tinca tinca & & 30 & & & 30 \\
\hline $\begin{array}{l}\text { Обыкновенная красноперка Scardinius erythrophthal- } \\
\text { mus }\end{array}$ & 1 & & & & 1 \\
\hline Обыкновенный жерех Aspius aspius & & & 4 & 1 & 5 \\
\hline Волжский подуст Chondrostoma variabile & & & 2 & & 2 \\
\hline $\begin{array}{l}\text { Семейство Карповые, ближе не определимые Cyprini- } \\
\text { dae }\end{array}$ & 12 & 26 & 21 & 34 & 93 \\
\hline Обыкновенный европейский сом Silurus glanis & 3 & & 5 & 2 & 10 \\
\hline Обыкновенная щука Esox lucius & 4 & & 5 & 3 & 12 \\
\hline Белорыбица Stenodus leucichthys & 73 & 143 & 5 & 9 & 230 \\
\hline Европейский хариус Thymallus thymallus & 9 & & & & 9 \\
\hline Каспийский лосось Salmo trutta caspius & 18 & 11 & 7 & 15 & 51 \\
\hline Лососевые, ближе не определимые Salmonidae & & 1 & & & 1 \\
\hline Речной окунь Perca fluviatilis & & 3 & 1 & 1 & 5 \\
\hline Обыкновенный судак Sander lucioperca & 85 & 42 & 84 & 110 & 321 \\
\hline Семейство Окуневые, ближе не определимые Percidae & 1 & & 4 & & 5 \\
\hline $\begin{array}{l}\text { Костистые рыбы, ближе не определимые Teleostei } \\
\text { (надотряд) }\end{array}$ & 29 & 6 & 87 & 48 & 170 \\
\hline Всего костей/чешуи рыб & $647 / 1$ & $698 / 2$ & 327 & 449 & 2115 \\
\hline Всего видов рыб & 17 & 17 & 17 & 13 & 23 \\
\hline \multicolumn{6}{|l|}{ Класс ПТИЦЫ AVES } \\
\hline Серощёкая поганка Podiceps grisegena & 1 & & & & 1 \\
\hline Пискулька Anser erythropus & 1 & & & & 1 \\
\hline Гуменник Anser fabalis & 6 & & & & 6 \\
\hline Домашний гусь Anser anser f. domestica & 27 & 15 & 25 & 17 & 84 \\
\hline $\begin{array}{l}\text { Домашний/серый гусь Anser anser f. domestical } \\
\text { Anser anser }\end{array}$ & 8 & & 2 & 1 & 11 \\
\hline Гусь, ближе не определимый Anser sp. & 9 & 1 & 7 & 3 & 20 \\
\hline Кряква Anas platyrhynchos & 12 & 12 & & & 24 \\
\hline $\begin{array}{l}\text { Кряква/Домашняя утка Anas platyrhynchos/ } \\
\text { Anas platyrhynchos f. domestica }\end{array}$ & 9 & 3 & 10 & 5 & 27 \\
\hline Домашняя утка Anas platyrhynchos f. domestica & 3 & & 2 & & 5 \\
\hline Серая утка Anas strepera & 4 & & & & 4 \\
\hline
\end{tabular}




\begin{tabular}{|c|c|c|c|c|c|}
\hline Чирок-свистунок Anas crecca & & 3 & & & 3 \\
\hline Свиязь Anas penelope & 2 & 1 & 2 & & 5 \\
\hline Шилохвость Anas acuta & 3 & 1 & 1 & & 5 \\
\hline Чирок-трескунок Anas querquedula & 3 & & & & 3 \\
\hline Широконоска Anas clypeata & 1 & & 2 & 1 & 4 \\
\hline Утка, ближе не определимая Anas sp. & 5 & 2 & 4 & 3 & 14 \\
\hline Морянка Clangula hyemalis & 1 & & & & 1 \\
\hline Белоглазый нырок Aythya nyroca & & 1 & & & 1 \\
\hline Длинноносый крохаль Mergus serrator & & 1 & & & 1 \\
\hline Большой крохаль Mergus merganser & & 1 & & & 1 \\
\hline Ястреб-тетеревятник Accipiter gentilis & 23 & 3 & & 3 & 29 \\
\hline Ястреб-перепелятник Accipiter nisus & 5 & & & 2 & 7 \\
\hline Беркут Aquila chrysaetos & 1 & & & & 1 \\
\hline Сапсан Falco peregrinus & 3 & & & & 3 \\
\hline Кречет Falco rusticolus & 1 & & & & 1 \\
\hline Тетерев Lyrurus tetrix & 11 & 6 & 5 & 2 & 24 \\
\hline Глухарь Tetrao urogallus & 1 & 1 & 2 & & 4 \\
\hline Рябчик Tetrastes bonasia & & 2 & & & 2 \\
\hline Домашняя курица Gallus gallus $f$. domestica & 488 & 468 & 247 & 295 & 1498 \\
\hline Куриные, ближе не определимые Galliformes & & & 20 & 7 & 27 \\
\hline Перепел Coturnix coturnix & 1 & 3 & & & 4 \\
\hline Серый журавль Grus grus & 1 & & & & 1 \\
\hline Лысуха Fulica atra & 1 & & & & 1 \\
\hline Погоныш-крошка Porzana pusilla & & & & 3 & 3 \\
\hline Чибис Vanellus vanellus & & 3 & & & 3 \\
\hline Вальдшнеп Scolopax rusticola & & 1 & & & 1 \\
\hline Большой улит Tringa nebularia & & & & 1 & 1 \\
\hline Турухтан Philomachus pugnax & 3 & & 1 & & 4 \\
\hline Вяхирь Columba palumbus & 4 & & 1 & 1 & 6 \\
\hline Сизый голубь Columba livia & 10 & 3 & 2 & 5 & 20 \\
\hline Голубь, ближе не определимый Columba sp. & 1 & & & & 1 \\
\hline Деревенская ласточка Hirundo rustica & & & & 2 & 2 \\
\hline Обыкновенный скворец Sturnus vulgaris & 1 & 4 & 2 & 3 & 10 \\
\hline Сорока Pica pica & 1 & & & & 1 \\
\hline Галка Corvus monedula & & & 1 & & 1 \\
\hline Домовый воробей Passer domesticus & & 2 & & & 2 \\
\hline Полевой воробей Passer montanus & & & 1 & 1 & 2 \\
\hline Птицы, ближе не определимые & & 1 & 5 & & 6 \\
\hline Всего костей птиц & 651 & 538 & 342 & 355 & 1886 \\
\hline Всего видов птиц & 28 & 19 & 16 & 15 & 43 \\
\hline
\end{tabular}

может прямо указывать на их совместное содержание человеком, тогда как в природных условиях эти виды занимают различные экологические ниши. Присутствие остатков ловчих птиц на небольшой площади позволяет выдвинуть предположение о наличии практики соколиной охоты, а также является еще одним свидетельством элитности изученного раскопом участка города и высокого социального статуса его жителей. Среди костных остатков птиц из средневековых напластований определены кости 7 синантропных видов, которые тесно связаны в своем распространении с крупными поселениями человека: сизый голубь, обыкновенный скворец, домовый и полевой воробьи, галка, деревенская ласточка, сорока. Для средневековых архео- логических памятников Среднего Поволжья такая концентрация остатков от нескольких видов синантропных птиц выявлена впервые (Аськеев и др., 2013б, табл. 1, с. 119-121; Аськеев и др., 2013в, с. 74-75; Galimova et al, 2014, p. 349-350).

\section{Заключение}

Результаты исследования археозоологической коллекции раскопа XLIV Билярского городища выявило высокое видовое разнообразие рыб и птиц. Преобладание остатков от крупноразмерных и ценных видов рыб, прежде всего осетровых и лососевообразных, может подтверждать высокий экономический и социальный статус Биляра. По обработанной коллекции остатков рыб из данного раскопа сформировалось абсолютно новое 
представление о характере рыбного рациона населения средневекового Биляра. Видовой состав археоихтиологической коллекции из центральной части Билярского городища демонстрирует его уникальность и в то же время эталонность потребления рыбы в крупном центре урбанизации Восточной Европы домонгольского времени. Высокое разнообразие диких птиц, найденных на одном местонахождении, служит доказательством высокой аккумуляционной способности различных природных ресурсов для жизнеобеспечения, что так же характерно для поселений с высоким социальным статусом.

\section{ЛИТЕРАТУРА}

Аськеев И.В., Галимова Д.Н., Аськеев О.В. Ихтиофауна позднего голоцена Средневолжского бассейна (по материалам археологических раскопок) // Зоологический журнал. 2013а. Т. 92. №. 9. С. 1014-1030.

Аськеев И.В., Галимова Д.Н., Аськеев О.В. Птицы Среднего Поволжья в V-XVIII вв. н.э. (по материалам археологических раскопок) // Поволжская археология. 2013б. № 3 (5). С. 116-144.

Аськеев И.В., Галимова Д.Н., Аськеев О.В. Домашние и дикие птицы из средневековых археологических памятников Среднего Поволжья // Динамика современных экосистем в голоцене / Материалы Третьей Всероссийской научной конференции (с международным участием). Казань: Отечество, 2013в. C. $72-77$.

Бадеев Д.Ю., Худяков А.В., Шакиров З.Г. Археологические исследования на территории Билярского комплекса в 2016-2017 гг. // Археологические открытия. 2017 год / Отв. ред. Н.В. Лопатин. М.: ИА РАН, 2019. C. 331-334.

Галимова Д.Н., Аськеев И.В., Аськеев О.В. Изучение остатков рыб и птиц из археологических раскопок древних городов Биляр, Болгар и Свияжск // Труды IV (XX) Всероссийского археологического съезда в Казани. Т. V. / Отв. ред. А.П. Деревянко, Н.А. Макаров, А.Г. Ситдиков. Казань: Отечество, 2015. С. 35-37.

Худяков А.В., Набиуллин Н.Г., Шакиров 3.Г., Шорохов М.В. Археологические Раскопки на территории Билярского городища и Балынгузского кладбища в 2018-2019 гг. // Археологические открытия. 2019 год. (В печати).

Хузин Ф.Ш., Шакиров З.Г. Археологические исследования на Билярском городище // Археологические открытия. 2015 год / Отв. ред. Н.В. Лопатин. М.: ИА РАН, 2017. С. 326-328.

Шаймуратова Д.Н. Особенности изучения субфоссильных остатков рыб и птиц из археологических памятников Среднего Поволжья и их экологическая интерпретация // Российский журнал прикладной экологии. 2016. № 1. С. 8-13.

Galimova D.N., Askeyev I.V. and Askeyev O.V. Bird Remains from $5^{\text {th }}-17^{\text {th }}$ Century AD Archaeological Sites in the Middle Volga Region of Russia // International Journal Osteoarchaeology. Special Issue. 2014. P. 347-357.

Honka J., Heino M.T., Kvist L., Askeyev I.V., Shaymuratova D.N., Askeyev O.V., Askeyev A.O.,Heikkinen M.E., Searle J.B., Aspi J. Over a thousand years of evolutionary history of domestic geese from Russian archaeological sites, analysed using ancient DNA. 2018. Genes. №9 (7). P. 367.

Lebrasseur O., Shaymuratova D., Askeyev A., Asylgaraeva G., Frantz L., Larson G., Askeyev O., Askeyev I. A zooarchaelogical and molecular assessment of ancient Chicken remains from Russia // Поволжская археология. 2021. №1 (35). С. 216-231.

Serjeantson D. Birds. Cambridge Manuals in Archaeology. New York: Cambridge University Press, 2009. $512 \mathrm{p}$.

\section{Информация об авторах:}

Шаймуратова Диляра Наилевна, научный сотрудник, Институт проблем экологии и недропользования AH РТ (г. Казань, Россия); galimovad@gmail.com

Аськеев Игорь Васильевич, кандидат биологических наук, доцент, старший научный сотрудник, Институт проблем экологии и недропользования АН РТ (г. Казань, Россия); archaeozoologist@yandex.ru

Шакиров Зуфар Гумарович, кандидат исторических наук, директор, Билярский государственный историко-археологический и природный музей-заповедник (с. Билярск, Россия); доцент, Казанский (Приволжский) федеральный университет (г. Казань, Россия); zufar_alchi@mail.ru 


\section{REFERENCES}

Askeyev, I. V., Galimova, D. N., Askeyev, O. V. 2013a. In Zoologichesky zhurnal (Russian Journal of Zoology) 9(92), 1014-1030 (in Russian).

Askeyev, I. V., Galimova, D. N., Askeyev, O. V. 2013b. In Povolzhskaya arkheologiya (Volga River Region Archaeology) 5 (3), 116-144 (in Russian).

Askeyev, I. V., Galimova, D. N., Askeyev, O. V. 2013v. In Askeyev, I. V., Ivanov, D. V. (eds.). Dinami$k a$ sovremennykh ekosistem $v$ golotsene (The Dynamics of Modern Ecosystems in the Holocene). Kazan: "Otechestvo" Publ., 72-77 (in Russian).

Badeev, D. Yu., Khudyakov, A. V., Shakirov, Z. G. 2019. In Lopatin, N. V. (ed.). Arkheologicheskie otkrytiia 2017 g. (Archaeological Discoveries in 2017). Moscow: Institute of Archaeology, Russian Academy of Sciences, 331-334 (in Russian).

Galimova, D. N., Askeyev, I. V., Askeyev, O. V. 2015. In Sitdikov A. G., Makarov N. A., Derevianko A. P. (eds.). Trudy IV (XX) Vserossiiskogo arkheologicheskogo s"ezda v Kazani (Proceedings of the $4^{\text {th }}\left(20^{\text {th }}\right.$ ) All-Russian Archaeological Congress in Kazan) V. Kazan: "Otechestvo" Publ., 35-37 (in Russian).

Khudyakov, A. V., Nabiullin, N. G., Shakirov, Z. G. Shorokhov, M. V. In Print. Arkheologicheskie otkrytiia 2019 g. (Archaeological Discoveries in 2019). (in Russian).

Khuzin, F. Sh., Shakirov, Z. G. 2017. In Lopatin, N. V. (ed.). Arkheologicheskie otkrytiia 2015 g. (Archaeological Discoveries in 2015). Moscow: Institute of Archaeology, Russian Academy of Sciences, 326-328 (in Russian).

Shaymuratova, D. N. 2016. In Rossiyskiy zhurnal prikladnoy ekologii (Russian Journal of Applied Ecology) 1. 8-13 (in Russian).

Galimova, D. N., Askeyev, I. V. and Askeyev, O. V. 2014. In International Journal Osteoarchaeology. Special Issue. 347-357 (in English).

Honka, J., Heino, M. T., Kvist, L., Askeyev, I. V., Shaymuratova, D. N., Askeyev, O. V., Askeyev, A. O., Heikkinen, M. E., Searle, J. B., Aspi, J. 2018. In Genes. 9 (7), 367 (in English).

Lebrasseur, O., Shaymuratova, D., Askeyev A., Asylgaraeva, G., Frantz, L., Larson, G., Askeyev, O., Askeyev, I. 2021. In Povolzhskaya arkheologiya (Volga River Region Archaeology) 35 (1), 216-231 (in English).

Serjeantson, D. Birds. 2009.Cambridge Manuals in Archaeology. New York: Cambridge University Press (in English).

\section{About the Authors:}

Shaymuratova Dilyara N. Researcher. The Institute of Problems in Ecology and Mineral Wealth, Tatarstan Academy of Sciences, Daurskaya St., 28, Kazan, 420087, Republic of Tatarstan, Russian Federation; galimovad@gmail.com

Askeyev Igor V. Candidate of Biology Sciences, Associate Professor, The Institute of Problems in Ecology and Mineral Wealth, Tatarstan Academy of Sciences, Daurskaya St., 28, Kazan, 420087, Republic of Tatarstan, Russian Federation; archaeozoologist@yandex.ru

Shakirov Zufar G. Candidate of Historical Sciences, Director of the Bilyar State Historical, Archaeological and Natural Museum-Reserve, Arbuzov Str., 2, Bilyarsk, 422920, Republic of Tatarstan, Russian Federation; Assistant Professor. Kazan (Volga Region) Federal University, Kremlevskaya, Str., 18, 420008, Kazan, Republic of Tatarstan, Russian Federation; zufar_alchi@mail.ru

Статья поступила в журнал 01.04.2021 г. Статья принята к публикации 01.04.2021 г. Авторы внесли равноценный вклад в работу. 